\title{
Bibliography of Publications by Chaim Seidler-Feller
}

\section{Articles}

1. "We Believe." In Elchanite, edited by Chaim Feller and Michael Novick, 88-89. Brooklyn: Students of Yeshiva University H.S. of Brooklyn, 1964.

2. "High Holy Day Messages." Ohio Jewish Chronicle (September 20, 1973): 11.

3. "Law and Changing the Law." Ha'Am (May 20, 1975): 9, 13. Republished with revisions as "The Public Invisibility of the Jewish Woman." Ohio Jewish Chronicle (June 5, 1975): 4; ibid. (June 12, 1975): 2, 13.

4. With Doreen Seidler-Feller. "Soviet Jew Writes from Israel." Ha'Am (April 19, 1977): 10.

5. "By Power and by Spirit." The Jewish Spectator 48, no. 3 (Fall 1983): 26-27.

6. "The Relationship between Judaism and Morality." Ha'Am (November 1983): 13.

7. “Female Rabbis, Male Fears." Judaism 33, no. 1 (Winter 1984): 79-84. Republished with revisions as "Opening the Last Door . . ." Ha'Am (March 1984): 8-9.

Because this bibliography was compiled without the honoree's knowledge, it likely does not represent the full extent of Rabbi Seidler-Feller's published oeuvre. Nevertheless, it is hoped that it may serve as a starting point for those interested in exploring his thought and activism. 
8. "Parshat Va-etchanan: Sounds of Silence." The Jewish Advocate (August 14, 1986): 6. Republished with revisions as "Vaetchanan: Attraction Based on Love, Not Magic." The Jewish World (August 15-21, 1986): 5.

9. "Hosting Dr. David Hartman: Hillel Welcomes Scholar, Philosopher, Rabbi: All in One." Ha'Am (November 1986): 15.

10. “A Common Heritage.” Ha’Am (January/February 1987): 4.

11. "The Land of Israel: Sanctified Matter or Mythic Space." Zionist Ideas 15 (Spring 1987): 6-31. Republished with addenda in Three FaithsOne God: A Jewish, Christian, Muslim Encounter, edited by John Hick and Edmund S. Meltzer, 137-64. Albany: State University of New York Press, 1989.

12. "Rebutting Avineri." Ha’Am (April 1987): 13.

13. “The Tension between Blacks and Jews." Daily Bruin (March 4, 1988): 15.

14. "Insults and Insensitivity Weaken Campus Relations." Daily Bruin (January 9, 1989): 22.

15. "Blacks and Jews: Troubled Times on the College Campus." Ha'Am (February 1989): 15. Republished with revisions as "Blacks and Jews: Troubled Times on the College Campuses." Tikkun 4, no. 3 (July/ August 1989): 92-94.

16. "Middle East: Keep the Proposals Realistic." Daily Bruin (February 7, 1989): 15.

17. “Yom Ha’atzmaut 1989." Ha’Am (April 1989): 12.

18. “Passover: A Taste of Freedom." Daily Bruin (April 12, 1990): 27.

19. "Jewish Life on Campus Today, 3." Shima: A Journal of Jewish Responsibility 20, no. 393 (April 27, 1990): 100-03.

20. "Between Assimilation and Identification." Shima: A Journal of Jewish Responsibility 21, no. 405 (January 11, 1991): 38-40.

21. "Not by Might and Not by Power: Kahanism and Orthodoxy" Tikkun 6, no. 1 (January/February 1991): 21-22.

22. With Jeffrey C. Alexander. "NOMMO Affair: Double Standard Can't Stand." Ha'Am (April 1991): 17, 29. Republished with revisions as "As Barriers Erode, Jews Face Unique Problems." Daily Bruin (May30, 1991): 24. Also republished with revisions as "The Effects of Anti-Semitism on UCLA." Jewish Journal (June 14-20, 1991). Also republished with revisions as "False Distinctions and Double Standards: The Anatomy of Antisemitism at UCLA." Tikkun 7, no. 1 (January/February 1992): $12-14$. 
23. "Response to Perry London and A[1]issa Hir[s]hfeld." In Jewish Identity in America, edited by David M. Gordis and Yoav Ben-Horin, 61-65. Los Angeles: Susan and David Wilstein Institute of Jewish Policy Studies, University of Judaism, 1991.

24. "Zionism Is Not a Racist Policy; It's Just a Form of Nationalism." Daily Bruin (January 15, 1992): 18.

25. "Judaism as a Choice in Our Materialistic Universe." The Jewish Spectator 58, no. 2 (Fall 1993): 40-43.

26. “Look within for the Personification of Evil." Los Angeles Times (March 14, 1994): B11. Accessed March 1, 2019. http://articles.latimes. com/1994-03-14/local/me-33777_1_hebron-massacre.

27. "Rabin Deserves Respect for Transformation toward Peace." Daily Bruin (November 13, 1995): 16, 19.

28. Essay in Rebuilding Jewish Peoplehood: Where Do We Go from Here? A Symposium in the Wake of the Rabin Assassination, edited by David A. Harris, 91-93. New York: American Jewish Committee, 1996. Republished with revisions as "The End of Illusion." Tikkun 11, no. 1 (January/February 1996): 76-77.

29. "Rabin's Legacy." Jewish Journal (December 9, 1996): 14, 26.

30. “Zionist Principles Can Drive Healing Process." Daily Bruin (May 6, 1997): 15.

31. "Unity with Diversity: The Hillel Path." Jewish Journal (May 30, 1997): 15.

32. “Alternative Sh'ma Explanation." In UCLA Hillel Siddur le-Shabbat, edited by Rachel Leslie Metson and Mayim Chaya Bialik, 35. Los Angeles: UCLA Hillel, 1999.

33. "Judaism's Womb." OLAM Magazine (Spring 2000): 10.

34. With David N. Myers. "Jews Shouldn't Adulate Temple Mount." Los Angeles Times (January 21, 2001): M5. Accessed March 1, 2019. http:// articles.latimes.com/2001/jan/21/opinion/op-14982.

35. "King David's Greatest Victory." OLAM Magazine (Winter 2001): 47.

36. "Israel's Solid Case Doesn't Need Exaggeration." Daily Bruin (June 5, 2002). Accessed March 1, 2019. http://dailybruin.com/2002/06/05/ israels-solid-case-doesnt-need/.

37. "Freedom to Doubt." OLAM Magazine (Summer 2002): 5.

38. "Reality for Campus Ills." Jewish Journal (December 19, 2002). Accessed March 1, 2019. https://jewishjournal.com/opinion/7168/. 
39. "'Sense of Siege' at UCLA Requires Strategic Response." The Leader [newsletter of the Wexner Heritage Foundation] 3 (Spring 2003): 7-8.

40. "Conflict as Mitzvah." OLAM Magazine (Winter 2004): 7. Republished with revisions as "The Mitzvah of Conflict Resolution-on Campus." 9 Adar (2015). Accessed March 1, 2019. https://www.9adar.org/wpcontent/uploads/2015/10/The-Mitzvah-of-Conflict-Resolution-onCampus-by-Chaim-Seidler-Feller.pdf.

41. Essay in I Am Jewish: Personal Reflections Inspired by the Last Words of Daniel Pearl, edited by Judea and Ruth Pearl, 192-93. Woodstock, VT: Jewish Lights Publishing, 2004.

42. "Sadness in the Context of Illness: A Jewish Perspective." The Yale Journal for Humanities in Medicine (February 5, 2005). Accessed March 10, 2019. http://yjhm.yale.edu/archives/spirit2004/sadness/ cseidler-feller.htm.

43. "Advocacy and Education as Divergent Strategies in the Effort to Support Israel on Campus." In American Jewry and the College Campus: Best of Times or Worst of Times?, edited by Harold T. Shapiro and Steven Bayme, 32-39. New York: Dorothy and Julius Koppelman Institute on American Jewish-Israeli Relations, American Jewish Committee, 2005.

44. “Different Tack on Campus Challenge." Jewish Journal (June 22, 2006). Accessed March 1, 2019. https://jewishjournal.com/news/los_angeles/ community/13274/. Abridged and revised as "Reconciliation and Renewal." Jewels of Elul (August 28, 2006). Accessed March 10, 2019. https://www.jewelsofelul.com/jewels/2006-5766/.

45. "The Withering of the Zionist Dream: Reflections on the Occupation after 40 Years." In A Rabbinic Guide to 40 Years of Occupation, edited by John Friedman and Aliza Becker, 18-19. Chicago: Brit Tzedek v'Shalom, 2007. Accessed March 1, 2019. http://btvshalom.org/ btvshalom.org/resources/rabbisguide.pdf.

46. Essay in "Jewish Spirituality in America: Listening to a Different Drummer: A Symposium." Havruta 3 (Spring 2009): 10-12. Accessed March 1,2019.https://shi-webfiles.s3.amazonaws.com/Havruta_2009_ Issue3_JewishSpiritualityInAmerica.pdf.

47. "A Jewish Golden Age on Campus." The Jewish Week (January 10, 2012). Accessed March 1, 2019. https://jewishweek.timesofisrael.com/ a-jewish-golden-age-on-campus/. 
48. With Keri Copans et al. “The Truth about UC Campuses." Jewish Journal (March 8, 2012). Accessed March 1, 2019. https://jewishjournal.com/ opinion/101856/.

49. “My Ima, Peppi Feller.” Jewish Journal (January 30, 2013). Accessed March 10, 2019. https://web.archive.org/web/20130204204552/http:// www.jewishjournal.com/obituaries/article/my_ima_peppi_feller.

50. "Omar Barghouti at UCLA: No to BDS, No to Occupation." Jewish Journal (January 23, 2014). Accessed March 1, 2019. https:// jewishjournal.com/opinion/126296/.

51. "They're Attacking Us with Missiles." Jewish Journal (July 15, 2014). Accessed March 1, 2019. https://jewishjournal.com/opinion/130880/.

52. With Aaron Lerner. "Increasingly Blurred Lines between Politics and Hate on Campus." UCLA Hillel (February 27, 2015). Accessed March 1, 2019. http://www.uclahillel.org/increasingly_blurred_lines_between_ politics_and_hate_on_campus.

53. With David N. Myers and Maia Ferdman. "UCLA Must Take Action to Address Anti-Semitism." Jewish Journal (March 11, 2015). Accessed March 1, 2019. https://jewishjournal.com/opinion/164300/.

54. "Strangers, Forever!" UCLA Hillel (April 3, 2015). Accessed March 1, 2019. http://www.uclahillel.org/passover_message_from_rabbi_ chaim_seidler_feller.

55. With David N. Myers. "These Rare Texts Will Remind You What Israel Once Aspired to Be." Forward (May 9, 2016). Accessed March 1, 2019. https://forward.com/opinion/340202/these-rare-texts-will-remindyou-what-israel-once-aspired-to-be/. Republished as "Renew Our Days as of Old." Jewish Journal (May 26, 2016). Accessed March 1, 2019. https://jewishjournal.com/opinion/185819/.

56. “Theo Bikel: A Memorial." Jewish Journal (June 17, 2016). Accessed March 1, 2019. https://jewishjournal.com/culture/186480/.

57. “The Akedah Dilemma." Jewish Journal (September 19, 2017). Accessed March 1, 2019. https://jewishjournal.com/culture/religion/high_holy_ days/224707/the-akedah-dilemma/.

58. “Reclaiming Activism." Sh'ma Now (March 2, 2018). Accessed March 1, 2019. https://forward.com/shma-now/returning/395525/reclaimingactivism/. 
lii $\mid$ Swimming against the Current

59. Commentary on "Notes for Symposium on Black Power[,] January 6, 1967." In The Eternal Dissident: Rabbi Leonard I. Beerman and the Radical Imperative to Think and Act, edited by David N. Myers, 138. Oakland, CA: University of California Press, 2018.

60. With David N. Myers. "Op-Ed: In Going after UCLA, the Trump Administration Is Attempting to Chill Free Speech about Israel." Los Angeles Times (January 23, 2020). Accessed January 30, 2020. https:// www.latimes.com/opinion/story/2020-01-23/in-going-after-ucla-thetrump-administration-is-attempting-to-chill-free-speech-about-israel.

\section{Letters}

1. With Roger C. Klein, Marc Lee Raphael, and David W. Zisenwine. Ohio Jewish Chronicle (September 19, 1974): 2.

2. Dialogue: New Jewish Leadership 1, no. 7 (Shavuot 1975): 2.

3. With Joe Maizlish et al. Ha'Am (November 27, 1979): 9.

4. Daily Bruin (February 7, 1983): 11.

5. Ha’Am (May 1983): 3.

6. Los Angeles Times (July 29, 1984), pt. IV, 4.

7. Los Angeles Times (July 26, 1986). Accessed March 1, 2019. http:// articles.latimes.com/1986-07-26/local/me-173_1_san-diego.

8. Daily Bruin (February 10, 1987): 15.

9. Daily Bruin (May 19, 1988): 22.

10. With David N. Myers. Daily Bruin (March 3, 1994): 18.

11. With David N. Myers. Los Angeles Times (March 4, 1994). Accessed March 1, 2019. http://articles.latimes.com/1994-03-04/local/me29773_1_settler-jewish-history-west-bank-and-gaza.

12. Los Angeles Times (October 14, 2003). Accessed March 1, 2019. http:// articles.latimes.com/2003/oct/14/opinion/le-simantob14.1.

13. Daily Bruin (January 24, 2007). Accessed March 1, 2019. http:// dailybruin.com/2007/01/24/letters_editor28/.

14. With Aaron Lerner. Jewish Journal (October 30, 2013). Accessed March 10, 2019. https://jewishjournal.com/letters_to_the_editor/122913/.

15. Jewish Journal (March 18, 2015). Accessed March 1, 2019. https:// jewishjournal.com/letters_to_the_editor/164915/.

16. Jewish Journal (August 3, 2018). Accessed March 1, 2019. https:// jewishjournal.com/letters_to_the_editor/236846/letters-editor-weekaugust-3-2018/. 